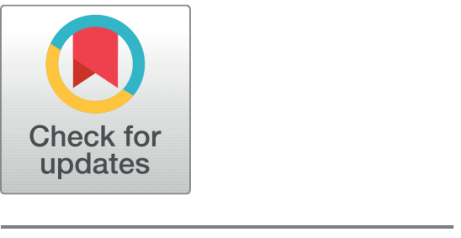

OPEN ACCESS

Received: 15-05-2020

Accepted: 10-06-2020

Published: 24-06-2020

Editor: Dr. Natarajan Gajendran

Citation: Ali S, Haq AU, Hamid S, Afrasiab (2020) Communication strategy of Khyber Pakhtunkhwa Government in Pandemic: a case study of Corona virus (COVID-19). Indian Journal of Science and Technology 13(22): 2175-2181. https ://doi.org/10.17485/IJST/v13i22.616

* Corresponding author.

Sajjad Ali

Assistant Professor, Department of Journalism \& Mass Communication, University of Malakand, Chakdara, Dir Lower, KP

sajjadjmc@uom.edu.pk

Funding: None

Competing Interests: None

Copyright: (c) 2020 Ali, Haq, Hamid, Afrasiab. This is an open access article distributed under the terms of the Creative Commons Attribution License, which permits unrestricted use, distribution, and reproduction in any medium, provided the original author and source are credited.

Published By Indian Society for Education and Environment (iSee)

\section{Communication strategy of Khyber Pakhtunkhwa Government in Pandemic: a case study of Corona virus (COVID-19)}

\author{
Sajjad Ali ${ }^{*}$, Ata UI Haq ${ }^{2}$, Sardar Hamid ${ }^{3}$, Afrasiab ${ }^{4}$ \\ 1 Assistant Professor, Department of Journalism \& Mass Communication, University of \\ Malakand, Chakdara, Dir Lower, KP \\ 2 Press Registrar in Information and Public Relations Department, KP and PhD Scholar, Ripha \\ Institute of Media Science, Ripha International University, Al-Meezan Campus Rawalpindi \\ 3 Assistant in Information and Public Relations Department, KP and PhD Scholar, Ripha \\ Institute of Media Science, Ripha International University, Al-Meezan Campus Rawalpindi \\ 4 Assistant in Information and Public Relations Department, KP and M.Phil Scholar, Islamic \\ International University, Islamabad
}

\section{Abstract}

Objective: In every country, authorities develop strategies for the awareness, education and information at the time of a crisis. This study explored the communication strategies of Khyber Pakhtunkhwa (KP) Government of Pakistan during the Corona virus (COVID-19)pandemic. Methods: Data was collected from the information department of KP. Secondary data was analyzed which was collected from the main information department Peshawar and the regional offices: Mardan, Abatabad, DI Khan, Malakand and Swat. Data was presented in a tabulated form in frequency distribution. Findings: The information department has used all type of methods, tactics and sources of information for the education, awareness and information of the public regarding Coronavirus (COVID-19) and made it possible to control the outbreak to a greater extent. KP government used all kind of media communication strategies including print media, radio, information departments, social media, videos and public service message for creating awareness among public. Recommendations: It is recommended that KP government until now has applied impressive communication strategies. It has been suggested to the government to use local influential public figures and places for the awareness of the people to overcome and control the pandemic.

Keywords: Coronavirus (COVID-19); communication strategies; tactics; methods; sources of information; Khyber Pakhtunkhwa; Pakistan

\section{Introduction}

The mass communication strategies have to be assessed for their effectiveness for health risk communications to cover diverse sections of public to generate cooperation with the governing agencies so as to contain and confront the pandemic. Educating the mass 
about self-protection and risk factors, means and ways of implementing the same simultaneously bringing the trust in authorities and busting the myths can be effectively performed.

The studies to assess the impact of health interventions by way of immunization in the scenario of COVID19 pandemic would be highly beneficial. A study was conducted to find out the difference in effect between men and women after immunization against multiple diseases and their effects on fighting COVID-19 and overall health. It has been found that men were infected more than women as well as men were at higher risk of death as compare to women in the world. The study also found that unemployed and blue-collar-workers are more in risk comparatively than employers ${ }^{(1)}$.

Efectiveness of any existing methods of symptomatic therapy would aid the combat of the disease."Anticoagulant therapy mainly with low molecular weight heparin appears to be associated with better recovery in severe COVID-19 patients meeting SIC criteria or with markedly elevated D-dimer" ${ }^{(2)}$.

Almost all countries applies communication tools for the information of public through different strategies. The existing literature review explored that each country used different communication methods and sources for the awareness of their people. The findings showed that no empirical study has been done to find out effective sources of information in a pandemic situation to create awareness to the public on time in effective manner. It has been suggested to the researcher to conduct research to find out effective source of information in epidemic ${ }^{(3)}$.

Strategic communication is very important in today's life, because it is very conductive to academic and practical realities. It means to synchronize actions, images, messages and another form of engagement to influence, persuade and inform the selected people to support national goals. In strategic communication, coordination is the most important factor as well as the need of connectivity among the message, image and action. The message should be informative, persuasive and influential to take action by the target audiences for acquiring national goals and purposes ${ }^{(4)}$.

Strategic communication is the instrument and tool which empowers to support the national objective and goals. It is the way to change the behavior and attitude of the target audience towards national interest. It is basically to engage the audience message and action and also the process of listening, understanding and engagement ${ }^{(5)}$.

It is a procedure to provide actual and timely information to the audience to influence them by the communicator for the target objectives. The information should be delivered to the target audience through precise and fair way ${ }^{(6)}$.

Strategic communication is to sustain and a systematic activity conducted on tactical and operational level to develop and promote opinion and ideas to change behavior and attitude ${ }^{(7)}$.

Strategic communication is basically working for the public diplomacy to mold the opinion of the public towards a particular objective. It has a great impact on the public diplomacy, because the policy makers use various kind of tactics and methods of strategic communication to acquire their objectives ${ }^{(8)}$.

Strategic communication is very important for originating change as well as for administrative management. Organizational change need different strategies to improve and change the behavior and attitude of the working class in the organization. For the better results of the organization the managers should to apply strategic communication to change the practices of the target audiences $^{(9)}$.

\subsection{Strategic communication in Crisis}

Broadly speaking crises are of two types; natural crises and man-made crises. Natural crises and disasters are flood, tsunami, earthquake etc, while man-made contain organizational crises, militancy, terrorism, corruption, psychological warfare etc.

At the time of crisis, the strategic communicator and experts should have the quality to protect and defend the individual, community, nation and organization reputation and familiarity internationally.

The role of strategic communication in a crisis centers on the management of conflict between the organization and its important stakeholders ${ }^{(10)}$. An organization thrives or survives by focusing and managing the stakeholders ${ }^{(11)}$."

There are stages of crisis when it occurs including prodromal, acute, chronic and crisis resolution crisis ${ }^{(12)}$. Five different stages of crisis containing detection of crisis are; prevention or preparation, containment, recovery and learning stage ${ }^{(13)}$.

Crisis gives predictable results which largely destroy the reputation of services and products as well as the financial condition of the workers and organization. The author classified the kinds of crisis in misconduct, natural disasters, management failure, rumor, mega damages, technical collapse, human errors, mistakes and workplace violence ${ }^{(14)}$.

\subsection{Significance of Strategic Communication in Pakistan}

The significance of strategic communication lies in the fact that it connects the theoretical and practical sides of life connecting professionals from various walks of life and to the society as a whole. Without such effective methods instilling ideas and information across different factions of society is not possible. During an emergency the appropriate coordination of strategies 
become therefore indispensable.

It is a fact that media is the mirror of society, so the journalist apply the strategic communication tactics to connect the people and show the society problems and issues. The journalists also need to portray the developmental activities of the society to the public.

\subsection{Coronavirus (COVID-19 Situation in Pakistan}

Coronavirus (COVID-19) was declared as world epidemic and named Covid-19 on February 11, 2020, which is a type of Severe Acute Respiratory tract infecting virus-2' (SARS-CoV-2) ${ }^{(15)}$. The epidemic cases have been confirmed from Karachi and Islamabad on February 26, 2020 in Pakistan ${ }^{(16)}$.

Total 159 new cases were confirmed, 35 deaths and total nationwide cases were identified as 2450 in last 24 hoursconfirmed positive and 53,069 death were confirmed globally. Total number of regions and countries affected were $181^{(17)}$.

\subsection{Objectives}

- To find out strategic communication methods of KP government.

- To analyse the strategic communication tactics of KP government.

- To examine the sources of strategic communication of KP government.

\subsection{Research questions}

RQ1: How many sources the government of Pakistan used as strategic communication for Corona-19?

RQ2: What kinds of tactics and methods have been applied as strategic communication method by government of Khyber Pakhtunkhwa for Corona-19?

\section{Method of Data collection}

Secondary data was collected from the Provincial Government of Khyber Pakhtunwa about Corona virus-19. For better understating and authentic information the researcher collected data from Press of Information and Public Relations Department Khyber Pakhtunkhwa province Pakistan. In this regard the researcher contacted different authorities of the department as well as regional offices in province including Mardan, Malakand, Swat, Kohat, Abbottabad, DI Khan and Bannu, whereas they released 820 handouts from February 26, 2020 to April 02, 2020 to different media outlets in the country. Data was presented in tabulated form, while research questions were supported with frequency distribution.

Information and public relations department government of Khyber Pakhtunkhwa is a main provincial gate way of the government communication to the masses. Since its inception in 1946, one year prior to the emergence of Pakistan, the same department plays a role to bridge the government and public relations and inform the masses about activities of government for the welfare of public of province. A dedicated and automated media cell is operating in civil secretariat of Peshawar which monitors the print and electronic media contents for knowing the negative and positive perception of media regarding the incumbent government and then reciprocate the version of government through media. Likewise a press secretary unit performs duty at chief minister Secretariat which has the responsibilities of media management public relation and press coverage of the chief minister while a same subsidiary unit of PRO office also exists in Governor House. Apart from that the department deputes a PRO to each department cabinet member and speaker for the media communication and PR responsibilities of the same authorities. The department hold an office at federal capital Islamabad to perform the responsibilities on behalf of the department while 7 field formations operates in the province at regional. These formations called the Regional Information Offices situated at Mardan, Malakand, Swat, Kohat, Abbottabad, DI Khan and Bannu. Research has shown that community media and broadcasting is a key for the awareness of rural communities and with this analogy the government flourishing the installation of FM radios in the province as it is a major source of information, education and public awareness in the rural areas of the province. Till now 04 Radio Stations owned by information department, one each in Peshawar, Mardan Kohat and Swat are running its broadcasts while due to the merger of erstwhile FATA a number of radio stations from FATA is also transferred in the control of provincial information department.

\section{Results and Discussion}

The findings were presented in the following tabulations; 
Table 1. Overall information disseminated through various ways by KP government

\begin{tabular}{lll}
\hline Indicators & F & \% \\
\hline Print media & 220 news stories and 68 columns and articles & 45 \\
Print Ads & 03 & 0.46 \\
Press conference & 20 & 3.12 \\
Short videos & 60 & 9.38 \\
Info graphics \& Public service messages prepared & 220 & 34.42 \\
Live streams by Facebook and YouTube & 20 & 3.12 \\
Social media interactive sessions & 05 & 0.78 \\
Alert Short Message Service (SMS) by cell phones & 23 & 3.59 \\
FM radio broadcast & Public service messages (PSM) every 15 minutes \\
Public service messages by FM radio & Public service messages \\
Radio programs and interviews & Public service messages & \\
Radio clinic & Peshawar, Mardan, Swat and Abatabad \\
Total & 639 & 100 \\
\hline
\end{tabular}

\section{Regional offices awareness strategies for awareness of Corona-19 **}

\begin{tabular}{lllllll}
\hline & Mardan & Abatabad & Malakand & DI Khan & Swat & Total \\
\hline Handouts & 105 & 30 & 84 & 208 & 119 & 546 \\
Images & 105 & 42 & 26 & 152 & 114 & 439 \\
Social media posts /images & $*$ & 139 & $*$ & 170 & $*$ & $*$ \\
Social media videos /messages & $\star$ & 264 & $\star$ & $*$ & 264 \\
\hline
\end{tabular}

${ }^{*}$ Data was dispersed, that's way didn't provided

${ }^{* *}$ Data provided by the regional office authorities(Feb, 26 till April, 2, 2020)

Table 1 demonstrates overall information disseminated through various ways by the government of Khyber Pakhtunkhwa (KP) $45 \%$ through print media, $0.46 \%$ by prints Advertisements, $3.12 \%$ through press conferences, $9.38 \%$ by short videos, $34.42 \%$ through info graphics and public service messages, $3.12 \%$ by live streams through facebook and YouTube, $0.78 \%$ via social media interactive sessions and 3.59\% information were spread to alert short service messages by cell phones. While, information related Corona virus-19 was disseminated after every 15 minutes through FM radio from different parts of the province. Table also illustrates the regional offices information strategies about corona- 19 , their issues of 546 handouts, 439 images, 309 social media posts \& images and 264 social media videos \& messages from February 26 to April 2, 2020.

\section{Radio Awareness regarding Corona-19}

Khyber Pakhtunkhwa Government also tuned radio broadcasting for the awareness and information of the public from its regional offices. The details are following;

Table 2. Progress of Pakhtunkhwa Radio FM 92.2 Peshawar in mass awareness regarding Covid-19 Pandemic

\begin{tabular}{|c|c|c|}
\hline S\# & & Duration \& Time \\
\hline 1 & No of hours of broadcast on COVID-19 Through FM Radios & 16hrs/Day \\
\hline 2 & No. of Public Service Messages announced through FM Radios & 22 Total/ 1 after every 5 minutes \\
\hline 3 & No. of Radio Programs/Interviews conducted on COVID-19 & 26/week \\
\hline 4 & No. of episodes of 'Radio Clinic' program broadcasted via FM Radio Stations & 9 \\
\hline 5 & Prime Minister Imran khan Speech and massage to the nation. & $\begin{array}{l}\text { We Have aired every speech of Prime } \\
\text { Minister Imran khan Regarding Covid- } \\
19\end{array}$ \\
\hline 6 & CM Mehmood khan Speech and Massage to the nation. & $\begin{array}{l}\text { We Have aired every speech and mas- } \\
\text { sage of CM Mehmood khan to the } \\
\text { nation. }\end{array}$ \\
\hline 7 & Adviser to CM Mr. Ajmal Wazir Press conference and Covid-19 Updates & $\begin{array}{l}\text { We have aired every new update } \\
\text { regarding covid-19 on Pakhtunkhwa } \\
\text { Radio on daily basis. }\end{array}$ \\
\hline
\end{tabular}

Continued on next page 


\begin{tabular}{|c|c|}
\hline Table 2 continued & \\
\hline S\# & Duration \& Time \\
\hline Health Minister (Taimur Salim Jagrah) special Interview on Covid-19 & $\begin{array}{l}\text { We have aired special Interview on } \\
\text { Covid-19 of Health Minister (Taimur } \\
\text { Salim Jagrah) on Saturday 28th March } \\
2020 \text { at 07PM to 08PM }\end{array}$ \\
\hline
\end{tabular}

\section{Progress of Pakhtunkhwa Radio FM 92.6 Mardan in mass awareness regarding Covid-19 Pandemic}

\begin{tabular}{lll}
\hline S\# & & Duration \& Time \\
\hline 1 & No of hours of broadcast on COVID-19 Through FM Radios & 16hrs/Day \\
2 & No. of Public Service Messages announced through FM Radios & 50/Day \\
3 & No. of Radio Programs/Interviews conducted on COVID-19 & 8 \\
4 & COVID-19 awareness special transmission 2 hours a day & 26 hrs \\
\hline
\end{tabular}

\section{Progress of Pakhtunkhwa Radio FM 98 Swat in mass awareness regarding Covid-19 Pandemic}

\begin{tabular}{lll}
\hline S\# & & Duration \& Time \\
\hline 1 & Handouts issued & 119 \\
2 & Pictures issued & 114 \\
3 & Radio Clinic Programs & 48 \\
4 & Radio Clinic Hours & 112 Hours \\
5 & Religious awareness programs & 16 (Daily 1 Hour) \\
6 & General awareness campaign programs & 16 (Daily 1 Hour) \\
7 & Corona awareness Ads/PSA & $10^{*} 20^{*} 16=3200$ times \\
9 & District Administration's announcements & $5^{*} 10^{*} 16=800$ times \\
10 & DHO/Health messages & $3 * 8 * 16=384$ times \\
11 & News broadcast & $2 * 16=32$ times \\
\hline
\end{tabular}

Table 2 shows the progress of the Peshawar based radio. Pakhtunkhwa Radio Peshawar goes on air 16 hours a day. It has suspended its routine transmission and COVID-19 pandemic is highlighted in almost every program on daily basis. It has 22 different PSAs in different languages including Urdu, Pashto, Persian, Chitrali and Wazir dialect. These PSAs are aired every 5 minutes, totaling to 150 times a day. It has aired dedicated programs on COVID-19 with a total of 50 hours since February 26, 2020. The Table also demonstrates the progress of the Pakhtunkhwa radio Mardan. Furthermore, all presenters and RJs have been directed to create awareness regarding COVID-19 in their routine programs. Thus the issue is being highlighted throughout the transmission on daily basis.

To create awareness in general Public regarding the Corona Virus spread and to facilitate the general masses regarding their health/medical issues at their homes, after the closure of OPD services in Govt. hospitals and private clinics, the following activities were carried out through radio Swat. The transmission of Radio Pakhtunkhwa FM 98, Swat were increased from 08:00 Hours to 12:00 Hours daily.

RQ1: How many sources the government of Pakistan used as strategic communication for Corona-19?

Table 3. Sources of information for Corona-19 by KP government

\begin{tabular}{lll}
\hline Sources of information & Frequency & \% \\
\hline Print media & 291 & 85.84 \\
Social media & 05 & 1.47 \\
Press conference & 20 & 5.89 \\
Cell Phone & 23 & 6.78 \\
FM Radio & 15 minutes $^{\star}$ & \\
Airing a mass awareness TVC on mainstream TV channels & In pipeline \\
$\begin{array}{l}\text { Paid promotion of Videos, Infographics and other public service messages } \\
\text { through Social Media }\end{array}$ & In pipeline & \\
\hline
\end{tabular}

Continued on next page 


\begin{tabular}{llll}
\hline \multicolumn{2}{l}{ Table 3 continued } & & \\
\hline Sources of information & Frequency & $\mathbf{\%}$ & \\
\hline Total & $\mathbf{3 3 9}$ & $\mathbf{1 0 0}$ & \\
\hline
\end{tabular}

${ }^{\star}$ Public service messages, programs and interview were on-air from FM radio after every 15 minutes from 4 FM radio including Peshawar, Mardan, Swat and Abatabad.

** Airing a mass awareness TVC on mainstream TV channels \& Paid promotion of Videos, Infographics and other public service messages through Social Media in pipeline

Table 3 illustrates the methods of information whereas $85.84 \%$ used print media, $1.47 \%$ consumed social media, $5.89 \%$ information was given through press conferences, $6.78 \%$ by cell phones alerts and FM radios were used after every 15 minutes for this purpose.On the other side government of KP also prepared TVCs for different televisions and social media awareness. Print media played an effective role in pandemic risk communication ${ }^{(18,19)}$ Print media framed influenza epidemic positively and effectively which controlled the large effects of the crisis .

"Results show that media attention was immense, that news content stressed threat over precautionary measures, while the pattern of coverage tonality remained nebulous due to conflicting findings. The present review also revealed a critical gap in existing knowledge about the tone of media coverage on $\mathrm{H} 1 \mathrm{~N} 1$, and discusses implications for future research on dramatization of public health risks by the media" $(\mathrm{p} 1)^{(20)}$.

Youtube was also an effective source of information at the time of pandemic ${ }^{(21)}$ Twitter is an easy and successful sources of information ${ }^{(22)}$. Pandemics in the age of Twitter: content analysis of Tweets during the 2009 H1N1 outbreak. Press conference is a very easy and mass audience source of information at the time of disease outbreaks ${ }^{(23)}$.

RQ2: What kinds of tactics and methods have been applied as strategic communication method by government of Khyber Pakhtunkhwa for Corona-19?

\begin{tabular}{cll} 
Table 4. Tactics for dissemination of information for Corona-19 by KP governmen \\
\hline Tactics for dissemination of information & Frequency & $\mathbf{9}$ \\
\hline Infographics \& Pubic Services message prepared & 05 & 1.86 \\
News stories & 220 & 82.08 \\
Print media Ads & 20 & 7.46 \\
Columns and articles & 23 & 8.58 \\
Total & $\mathbf{2 6 8}$ & $\mathbf{1 0 0}$ \\
Methods for easy understanding of information & Frequency & $\mathbf{\%}$ \\
Press conference & 20 & 22.47 \\
Short videos & 60 & 67.41 \\
Social media interactive sessions & 05 & 5.61 \\
Radio Clinics & 4 & 4.49 \\
Total & $\mathbf{8 9}$ & $\mathbf{1 0 0}$ \\
\hline
\end{tabular}

Table 4 shows various tactics applied by the KP government for the awareness of information about Corona-19 that $1.86 \%$ was prepared Info graphics \& Pubic Services message, $82.08 \%$ was news stories, $7.46 \%$ was print media and $8.58 \%$ was column and articles. Every possible tactics of information was used for the global Tobacco epidemic in 2013, whereas all kind of advertisement and promotional information was banned ${ }^{(24)}$. Online services and social media contents were generated to communication with people at time of crisis ${ }^{(25)}$. "Mutual learning is not necessarily a good description of the movement of policies and suggest that analogies to disease and epidemics may be a useful way of thinking about what is happening"(26).

Table 4 also demonstrates methods applied by the KP government for easy understanding of information regarding Corona19 that $22.47 \%$ information were given by press conferences, 67.41 through short videos, $5.61 \%$ by social media interactive sessions and 4.49\% through FM radio clinics which were established in Peshawar, Mardan, Abatabad and Swat regions. During pandemic (H1N1) 2009 influenza (pH1N1) most effective sources of information were schools, friends, family, health professional and officials as well as media ${ }^{(27)}$. Traditional and information technologies were the methods for information and surveillance in epidemic ${ }^{(28)}$. Facebook is an effective source of information method in Zika viroius outbreak at the time Social media is very effective source of information in epidemic such as Corona-19. Traditional media and social media were applied for information of public about Corona-19.

\section{Conclusion}

It is concluded that in this critical situation like other governments, Khyber Pakhtunkhwa used all kind of sources, tactics and methods of information, awareness and educational programes about Corona-19. In this regard handout, images, public 
services messages were disseminated through different media outlet for general information about Coronavirus (COVID-19). Special Radio programs were transmitted and clinic started for the cause and effect of the disease. It is also concluded that government is using every possible tactics for the education of public to control and overcome the epidemic. On the bases of KP culture, it is suggested to the government to start campaign in Masjids (worship areas) and Hujras (Guesthouses) through spiritual leaders and opinion leaders as they are more influential in the areas to control the situation in the province of KP.

\section{References}

1) Tang N, Bai H, Chen X, Gong J, Li D, Sun Z. Anticoagulant treatment is associated with decreased mortality in severe coronavirus disease 2019 patients with coagulopathy. Journal of Thrombosis and Haemostasis. 2020;18(5):1094-1099. Available from: https://dx.doi.org/10.1111/jth.14817.

2) Tang N, Li D, Wang X, Sun Z. Abnormal coagulation parameters are associated with poor prognosis in patients with novel coronavirus pneumonia. Journal of Thrombosis and Haemostasis. 2020;18(4):844-851. Available from: https://doi:10.1111/jth.14768.

3) Savoia E, Lin L, Viswanath K. Communications in Public Health Emergency Preparedness: A Systematic Review of the Literature. Biosecurity and Bioterrorism: Biodefense Strategy, Practice, and Science. 2013;11(3):170-184. Available from: https://dx.doi.org/10.1089/bsp.2013.0038.

4) Paul C. Strategic Communication: Origins, Concepts, and Current Debates: Origins, Concepts, and Current Debates. and others, editor;ABC-CLIO. 2011.

5) Stavridis JG. Strategic communication and national security. UNITED STATES SOUTHERN COMMAND MIAMI FL. 2007. Available from: https: //apps.dtic.mil/dtic/tr/fulltext/u2/a575204.pdf.

6) Tatham S. US Governmental information operations and strategic communications: A discredited tool or user failure? Implications for future conflict. ARMY WAR COLLEGE CARLISLE BARRACKS PA STRATEGIC STUDIES INSTITUTE. 2013. Available from: https://apps.dtic.mil/dtic/tr/fulltext/u2/ a589976.pdf.

7) Lewis LK, Russ TL. Soliciting and Using Input During Organizational Change Initiatives. Management Communication Quarterly. 2012;26:267-294. Available from: https://dx.doi.org/10.1177/0893318911431804.

8) Coombs WT. and others, editor;Sage Publications. 2014

9) Fink S. Crisis management: Planning for the inevitable. American Management Association. 1986.

10) Pauchant TC, Mitroff II. Transforming the crisis-prone organization: Preventing individual, organizational, and environmental tragedies. and others, editor. 1992.

11) Zaremba AJ. Crisis Communication: Theory and Practice. Sharpe M, editor. 2010. Available from: https://doi.org/10.1177/1080569910385318.

12) Coronavirus. 2020. Available from: https://www.who.int/health-topics/coronavirus.DateAccessed.

13) .2020. Available from: https://www.dawn.com/news/amp/1536792Daily.

14) .2020. Available from: https://www.nih.org.pk/wp-content/uploads/2020/04/COVID-19.

15) Sandell T, Sebar B, Harris N. Framing risk: Communication messages in the Australian and Swedish print media surrounding the 2009 H1N1 pandemic. Scandinavian Journal of Public Health. 2013;41:860-865. Available from: https://dx.doi.org/10.1177/1403494813498158.

16) Olowokure B, Odedere O, Elliot AJ, Awofisayo A, Smit E, Fleming A, et al. Volume of print media coverage and diagnostic testing for influenza A(H1N1)pdm09 virus during the early phase of the 2009 pandemic. Journal of Clinical Virology. 2012;55(1):75-78. Available from: https://dx.doi.org/10. 1016/j.jcr.2012.05.013.

17) Klemm C, Das E, Hartmann T. Swine flu and hype: a systematic review of media dramatization of the H1N1 influenza pandemic. Journal of Risk Research. 2016;19(1):1-20.

18) Pandey A, Patni N, Singh M, Sood A, Singh G. YouTube As a Source of Information on the H1N1 Influenza Pandemic. American Journal of Preventive Medicine. 2010;38:e1-e3. Available from: https://dx.doi.org/10.1016/j.amepre.2009.11.007.

19) Chew C, Eysenbach G. Pandemics in the Age of Twitter: Content Analysis of Tweets during the 2009 H1N1 Outbreak. PLoS ONE. 2010;5(11):e14118e14118. Available from: https://dx.doi.org/10.1371/journal.pone.0014118.

20) Team EE. Pandemic alert level 6: scientific criteria for an influenza pandemic fulfilled. 2009.

21) .. Available from: https://www.who.int/tobacco/global_report/2013/en/.

22) Kavanaugh AL, Fox EA, Sheetz SD, Yang S, Li LT, Shoemaker DJ, et al. Social media use by government: From the routine to the critical. Government Information Quarterly. 2012;29:480-491. Available from: https://dx.doi.org/10.1016/j.giq.2012.06.002.

23) Levin B. An epidemic of education policy:(what) can we learn from each other. Comparative education. 1998;34(2):131-172. Available from: https: //doi.org/10.1080/03050069828234.

24) Kavanagh AM, Bentley RJ, Mason KE, Mcvernon J, Petrony S, Fielding J, et al. Sources, perceived usefulness and understanding of information disseminated to families who entered home quarantine during the H1N1 pandemic in Victoria, Australia: a cross-sectional study. BMC infectious diseases. 2011;11(1). Available from: https://link.springer.com/article/10.1186/1471-2334-11-2.

25) Briand S, Mounts A, Chamberland M. Challenges of global surveillance during an influenza pandemic. Public Health. 2011;125(5):247-256. Available from: https://dx.doi.org/10.1016/j.puhe.2010.12.007.

26) Sharma M, Yadav K, Yadav N, Ferdinand KC. Zika virus pandemic-analysis of Facebook as a social media health information platform. American Journal of Infection Control. 2017;45:301-302. Available from: https://dx.doi.org/10.1016/j.ajic.2016.08.022.

27) Chan AK, Nickson CP, Rudolph JW, Joynt AL. Social media for rapid knowledge dissemination: early experience from the COVID-19 pandemic. . Available from: https://doi.org/10.1111/anae.15057.

28) Odendaal WG. 2020. Available from: https://www.medrxiv.org/content/medrxiv/early/2020/04/14/2020.03.11.20034512.full.pdf. 